\title{
Choice and Freedom: Elusive Issues in the Search for Gender Justice
}

\author{
Gender Justice. By David L. Kirp, Mark G. Yudof, and Marlene \\ Strong Franks. University of Chicago Press, 1986. Pp. x, 205. \$19.95.
}

\section{Lucinda M. Finley†}

Particularly among feminist scholars, it is hardly fashionable anymore to adhere to liberal feminism. Its goals are largely limited to achieving the same rights and privileges for women as those held by men, without seriously questioning the existing values and structures of male-defined institutions. ${ }^{1}$ Against this increasingly skeptical background, Gender Justice ${ }^{2}$ stands out as an ardent defense of conventional liberalism-not even liberalism as refined by current liberal feminists to take power, domination, and the social construction of gender into account, ${ }^{3}$ but a nineteenthcentury brand of liberal philosophy evocative of Kant and Mill." The book is also reminiscent of an earlier era because, in terms of the positions the authors espouse, the issues they examine, and the social arrangements

$\dagger$ Associate Professor of Law, Yale Law School. The helpful comments of Drew Days, Jay Katz, Gary Minda, and Deborah Rhode are gratefully acknowledged.

1. For critiques of liberal feminism, see J. Elshtain, Public Man, Private Woman (1981); A. Jaggar, Feminist Politics and Human Nature 27-48, 173-203 (1983); Finley, Maternity and the Workplace: Transcending Equality Theory, 86 CoLum. L. Rev. 1118 (1986); MacKinnon, Feminism, Marxism, Method, and the State: An Agenda for Theory, 7 Signs 515 (1982).

2. D. KiRP, M. Yudof \& M. FRANKS, GendeR Justice (1986) [hereinafter cited by page number only].

3. For a discussion of liberal feminists' assessments of the social construction of gender and power relations, see A. JAGgar, supra note 1, at 175-81. See also Z. Eisenstein, Feminism and SEXUAL EQUALITY 189-254 (1984) (examining crisis of liberalism and radical potential of feminism to transform liberalism by exposing how patriarchal ideology has distorted women's reality and meaning of concepts such as "equality"); Williams, Equality's Riddle: Pregnancy and the Equal TreatmentI Special Treatment Debate, 13 N.Y.U. Rev. L. \& Soc. Change 325 (1985) (analyzing social construction of gender roles in pregnancy context and defending liberal approach of equal treatment).

4. Although the authors rely on J. MiLl, ON LiBErty (D. Spitz ed. 1974) (1859), see, e.g., pp. 14-16, 22, the lessons of Mill's essay The Subjection of Women seem lost on them. Mill, The Subjection of Women, in Feminism: The Essential Historical Writings (M. Schneir ed. 1972). In this essay Mill, displaying perceptions shared by the present day feminist "oppression theorists" derided by Kirp, Yudof, and Franks, discusses how women are socialized to be dependent, to devalue any sense of their own will, and to acquiesce in and contribute to their subordinate position. Mill decries men's efforts to generalize about "women's nature" as tainted by socialization and domination and cautions against reaching any conclusions "until women themselves have told all that they have to tell." Id. at 162, 173. Mill's insight is consistent with the arguments of modern day feminists that a governmental policy of blindness to gender, based on an ideal of liberty, can be problematic when applied against a background of the legally sanctioned subordination of women fostered and entrenched by socialization. 
they leave unchallenged, the work seems barely touched by the recent profusion of feminist writings on gender issues.

The guiding principle of the book's analysis is liberty, understood as the freedom to choose one's lifestyle, values, jobs, and relationships without government interference. The authors disavow any commitment to a particular distribution of resources, jobs, or social roles between men and women. Instead, they opt for an ostensibly outcome neutral, processoriented approach to gender issues. This approach

focuses primarily on how individuals exercise choice and the limits imposed on choosing. In this view, rules are needed to purge procedures of all unnecessary impediments, leaving individuals as free as possible to determine for themselves the relevance of gender. Choice itself, not some specified social arrangement, becomes the yardstick of goodness. ${ }^{5}$

The authors define justice as "enhancing choice for individuals, securing fair process rather than particular outcomes for the community"; and they "value self-determination over collective determinations of sex roles." The only appropriate role for government policy and law, under this view, is "to ensure that the public realm treats men and women as deserving of equal liberty." Government should not "set out to change ... private choices in the name of imposing a better kind of community," or seek to establish "some fixed set of outcomes, either sex-based indistinguishability or sex-based differentiations."

The authors illustrate their conception of gender justice with a story about the hypothetical state of Givitas. ${ }^{10}$ In this state, everyone works as either a butcher, a baker, or a candlestick maker. There are, however, sharp gender distinctions among the occupants of each job. Nine of ten butchers are men; bakers are evenly divided between the sexes, although women bakers concentrate primarily on making fancy toppings rather than the bread of life; and only one candlestick maker in ten is a man. A debate ensues between the Levellers, who see these statistics as evidence of sexism and call for policies designed to produce an equal division of the sexes in the two unbalanced occupations, and the Naturalists, who proclaim that the hand of nature is obviously at work and argue that justice requires leaving the natural order well enough alone. Sitting on the fence,

\footnotetext{
5. P. 12.

6. Id.

7. P. 81 .

8. Id.

9. P. 202.

10. Pp. 9-10.
} 
unable to draw firm conclusions from the bare situation, are the Liberals. ${ }^{11}$ This group is full of questions: How did this distribution come about? Does it reflect the real choices of men and women based on life needs and circumstances, or does it reflect the operation of prejudices and barriers that have forced men and women into these positions? If the former is true, then the "preferences deserve to be honored, for there is no 'right percentage' of male bakers or female butchers in all times and places."12 If the latter, "justice demands that government intervene to remove these barriers to choice."1s

Not surprisingly, the authors identify with the questioning Liberals. Their book is an effort to explain and to justify the liberal conception of gender justice as enhancing the autonomy of isolated, abstracted individuals.

The justification takes several forms. First, the authors caricature the explanations offered by "leftist feminists," who correspond to the Levellers in their story, and by right-leaning "Naturalists" for the current disparities of roles and economic positions between men and women. They criticize leftist feminists, a category they define to include radical feminists, Marxists, and socialist feminists, ${ }^{14}$ for focusing on women as members of a class, rather than as individuals who happen to be female. ${ }^{15} \mathrm{As}$ described by the authors, this group or class-based theory explains the position of women as the result of oppression by men, an oppression centered on women's sexuality and reproductive capacity. In the authors' view, the oppression theory can be readily dismissed as merely "a heuristic device for perceiving and organizing the present," rather than an "argument subject to proof or falsification."16 The oppression theory's most serious flaw, from the point of view of the authors who are committed to a conception of men and women as freely choosing, autonomous individuals, is that "it explains women's present condition in a way that absolves women from any responsibility for having entered into this condition. . . The idea of oppression thus creates a view of the world in which choice has no meaning, at least concerning present circumstance."17

\footnotetext{
11. Id.

12. P. 10 .

13. Id.

14. P. 48. The authors ignore the many differences between radical feminists, such as Catharine MacKinnon, Marxist feminists, such as Juliet Mitchell, and socialist feminists, such as Alison Jaggar. For a discussion of these distinctions, see A. JAGGAR, supra note 1, at 27-48, 83-118, 123-63. By lumping together positions that differ in sophisticated ways, the authors grossly oversimplify the oppression theories of the writers they discuss.

15. P. 48 .

16. P. 51 .

17. P. 52. The authors' characterization misunderstands the oppression theory. One aspect of that theory is to analyze how patterns of male domination create an atmosphere that makes women acquiesce in their roles. Rather than denying that women do and can make "choices," the theory questions
} 
Next, the authors take on the Naturalists, who, like the leftist feminists, see women as weak and dependent, but who ascribe this inferior state to biology rather than oppression. ${ }^{18}$ Naturalists explain the social and political dominance of men on the basis of fundamental physical, hormonal, or neurochemical differences between men and women, including different reproductive roles, the comparatively low level of aggression-fostering testosterone in women, and disparities in brain structures and sizes that affect verbal skills and facility for spatial relations. ${ }^{19}$ The authors criticize the Naturalists for ignoring the fact that the similarities between men and women are far more significant than the differences. As the biopsychologist on whom the authors rely observes, cross sex differences are " "rather minor compared to differences between people of the same sex: of all the variations we observe among people, eighty to ninety-five percent of them are within men and within women." "20 The Naturalist position also errs in seeing societally sanctioned limitations on women's roles as necessary and inevitable, legitimately enforced by coercion in the name of benevolent paternalism. This, of course, is highly offensive to a liberty-loving liberal (as well as to a leftist feminist who would be ever alert to the forms of socially constructed and contingent expectations regarding women that have justified patriarchy):

It also reveals the ahistoricity of the naturalist approach, its failure to note the possibility and reality of mediating nature's impact on the lives of men and women through education, technology, and politics. ... In its inattention to the possibility of political choice, naturalism also fails to recognize the relationship between "civilization," not just mere survival, and limitations on brute nature. The present is neither inevitable nor necessarily beneficent: this much we owe to politics and morality. ${ }^{21}$

Having thus disposed of both "feminism" and "naturalism" by arguing in a circular fashion that both are inconsistent with the assumptions underlying the choice principle they espouse, ${ }^{22}$ the authors further defend

the meaning and value of "choice" as currently defined. See infra notes 94-99 and accompanying text.

18. P. 53.

19. A classic example of the Naturalist view is S. Goldberg, The Inevitabiliry of PATRIARCHY (1973). Goldberg bases his position on the greater amount of testosterone in males, which gives them an advantage in strength and aggression. He sees this greater aggressiveness as the key to male dominance. For a critique of the flawed assumptions and methodologies of sociobiological theories about male superiority based on hormonal and neural differences, see R. BLEIER, SCIENCE AND GENDER 80-109 (1984).

20. Pp. 53-54 (quoting from J. DuRden-Smith \& D. de Simone, Sex and the Brain 62-63 (1983) (remarks of Jerre Levy)).

21. P. 55 (citation omitted).

22. The authors criticize the analysis of the Naturalists and the leftist feminists for having a common underlying weakness: 
the choice principle as the only alternative that devotes sufficient attention to policy, or politics, "as that term is conventionally understood" to include such concepts as citizenship and participation in public affairs. ${ }^{23}$ Their criticism of Naturalists for looking only to "science" is partly correct, but does not go far enough. Science is permeated with and part of "policy."24 When Naturalists justify their world view in scientific terms, they are making, and simultaneously masking, a profound policy judgment. The authors wrongly criticize the leftist feminists' agenda for not dealing with "politics" but with "something as diffuse, amorphous, and ubiquitous as 'the culture," "25 and for demanding fundamental changes in family structure and the world of work "without hinting how this profound transformation might be brought about."26 Although diffuse and omnipresent, the culture certainly has political implications and is an appropriate subject for policy, because virtually every policy initiative will affect and become part of the culture. Global attention to the intricate interweavings of family, market, and politics is not a fruitless enterprise simply because fundamental political and social change will be difficult to achieve, and because some of the specifics may elude us until we have a better grasp of the roots and implications of existing structures. ${ }^{27}$

[T]he paradigms stress what happens to women, rather than attributing to them any significant part in shaping their circumstances. Each of the paradigms ignores the existence of will; neither in the world of the naturalists nor in that of the leftist feminists do there exist morally responsible individuals. . . Biology, economics, or culture-not the actions of individuals-are regarded as controlling.

P. 63. This account misstates the attitudes of each position toward the will. Rather than ignoring the will, Naturalists assert that it cannot overcome biology. Leftist feminists assert that the will is strongly influenced by societal power dynamics. Moreover, the authors never defend their assertion that "free will" exists in individuals as something innate that develops and operates independently of biology and social relationships. See infra Section II. Nor do they consider the feminist criticism that individuated "autonomy" may not be the ideal aspiration in a world of interconnectedness. See infra Section III. Nor do they justify the assumption, implicit in their criticism quoted above, that constructs known as economics and culture are created and exist apart from the actions of individuals.

23. P. 57. The criticism that feminists do not speak in terms of politics as conventionally understood is particularly inapt, since a crucial point of feminist theory and methodology is to challenge the existing conception of politics. See, e.g., A. JAGGAR, supra note 1, at 133-48 (critiquing conception of politics that rests on public/private dichotomy); MacKinnon, supra note 1, at 534 (stating that "personal is political" to demonstrate how matters usually thought of as private or personal are played out in environment of power and domination and can be greatly influenced by public policies). Feminists argue that the acceptance of existing definitions of politics guarantees perpetuation of the existing order; it permits only political action within the framework of that order. See, e.g., K. FERGUSON, The Feminist Case Against Bureaucracy 154-212 (1984).

24. See E. Keller, Reflections on Gender AND Science (1985) (discussing ways in which notions of scientific "truth" are tied to political and historical currents, or to world views of largely male practitioners of science); T. KuHN, The Structure of ScIENTIFIC Revolutions (1962). The argument that because nature controls, nothing should be done to change the natural order is a policy argument. Moreover, as the authors recognize, the Naturalist position can lead to the advocacy of protective policies aimed at sheltering the reproductive capacities of women. See pp. 53-56.

25. P. 57.

26. P. 59 .

27. Although some feminist proposals are quite specific in advocating certain laws and policies, see, e.g., Frug, Securing Job Equality for Women: Labor Market Hostility to Working Mothers, 59 
After rejecting the explanations of nature and oppression as too extreme and portraying their view as the only defensible and reasonable middle ground, the authors explain the differences in social and economic positions of men and women as the consequences of paternalistic, protective labor and family policies prevalent from the late nineteenth century until quite recently. ${ }^{28}$ Paternalistic policies such as wage and hour legislation, ${ }^{20}$ restrictions on the jobs available to women ${ }^{30}$ and limitations on women's right to vote, to make contracts, and to own property are designed to keep women out of the rough and tumble public world and obviously constrain choice. ${ }^{31}$ These policies treat women as a class, rather than as individuals. ${ }^{32}$ They assume women's dependency and incapacity to make life choices. They are, in effect, self-fulfilling prophecies that produce dependency. ${ }^{33}$ This historical analysis provides the second major justification for the liberty and choice approach: This approach, according to the authors, will free us from the chains of protection and create a climate in which men and women will be on equal footing to determine their own destinies.

In pointing to benignly motivated ${ }^{34}$ paternalistic policies as the explanation for gender injustice, the authors intend to distinguish the basis of women's inferior status from that of blacks. Although blacks have certainly been the victims of paternalism, the authors view racial policies as motivated by prejudice and hatred and designed solely to oppress and

B.U.L. REv. 55, 94-103 (1979) (outlining four types of legislation to aid working mothers); Taub, From Parental Leaves to Nurturing Leaves, 13 N.Y.U. Rev. L. \& Soc. CHange 381 (1985) (advocating passage of federal parental leave legislation); Williams, supra note 3, other works criticized by Kirp, Yudof, and Franks, p. 59 (D. Dinnerstein, The Mermaid and the Minotaur (1976); N. Chodorow, The Reproduction of Mothering (1978)) and pp. 70-71 (C. Gilligan, In a DifFERENT VOICE (1982)), do not purport to be detailed blueprints for implementing change. The authors' criticism is misplaced. These works of theory, informed by experience, are offered in the hope that their insights will help us question the inevitability and impact of existing structures, in order to free the imaginations of policy makers and individual actors to try something new or struggle with reordering priorities.

28. Pp. 29-45.

29. See, e.g., Adkins v. Children's Hosp., 261 U.S. 525 (1923) (hours of work legislation); Muller v. Oregon, 208 U.S. 412 (1908) (same).

30. See, e.g., Dothard v. Rawlinson, 433 U.S. 321 (1977) (height and weight requirement); Goesaert v. Cleary, 335 U.S. 464 (1948) (to be bartender, woman must be wife or daughter of male owner); Bradwell v. Illinois, 83 U.S. (16 Wall.) 130 (1872) (women not biologically suited for practice of law).

31. The authors assert that paternalism is an evil because it "dictate[s] to men and women their best interests, convey[s] a sense of moral inferiority, and diminish[es] the sphere of liberty available to both sexes." P. 42.

32. P. 30 .

33. Pp. 33, 35.

34. They consider paternalistic policies towards women "benignly motivated" because, although misguided, they were intended to help and protect women, and were presumably motivated by affection and respect for the maternal function. Pp. -41-45. For works calling these "benign" motivations into question, see J. Baer, The Chains of Protection (1978); A. Kessler-Harris, Out To Work: A History of Wage-Earning Women IN the United States 180-214 (1982). 
guarantee subservience. ${ }^{35}$ Moreover, according to the authors, blacks were widely perceived to be inferior beings, whereas women were not: "While historically the state placed limits on women and treated them as less competent, it never denied women's basic humanity."36 The significance of this distinction is that the authors concede that otherwise paternalistic and choice retarding policies that are not race-blind, such as hiring preferences, still need to be employed to achieve racial justice. In their view, however, we have reached the stage where gender-blindness should be pursued in all policies. ${ }^{97}$

The authors' final strategy is to apply the choice principle to several policy issues and Supreme Court gender discrimination cases. The authors contend that while government is not supposed to constrain choice in any way, it should not sit by idly: "If liberty is to have meaning, individuals must have the opportunity to choose, the capacity to make choices, information on which to base preferences, and a climate of tolerance in which to explore alternatives."38 Thus, government policy should actively prohibit discrimination, because discrimination "robs individuals of the chance to make important life determinations for themselves."39 This will require the abandonment and proscription of old practices, as well as positive initiatives, such as publicizing the removal of old barriers. To guarantee that individuals have the capacity to make choices, government should also ensure that everyone's basic social and economic wants are satisfied. Nevertheless, to avoid an expansion of state authority that would subsume individual choice to the collective will, government should restrict itself to the satisfaction of minimum needs, by, for example, providing a guaranteed income, rather than attempting wholesale redistributions of resources. ${ }^{40}$

The authors summarize their blueprint for government action as "[p]rotecting against discrimination, intervening in instances of market failure, providing minimum economic support, disseminating information [and] promoting tolerance," but not "imposing a particular conception of

35. Pp. 43-44.

36. P. 203. This assertion is strongly refuted by Gunnar Myrdal's classic study of racism in America, in which he explores the parallels between racism and sexism. G. MYrdal, AN AMERICAN DrLemma (1962). Myrdal demonstrates that paternalistic policies toward both women and blacks were based on assumptions about their mental and emotional inferiority, their circumseribed proper places in society, their contented acceptance of their lots, and the benevolence of the protection accorded them by the law and the social conventions of white men. This "protection" for blacks and women included denial of political franchise, restrictions on education, and relegation to low-paying, low-status jobs. Id. at 1073-78.

37. P. 45.

38. P. 131.

39. P. 132.

40. Pp. 133-34. 
virtue."41 Applying these guidelines, the authors oppose comparable worth policies because they believe choice and preference, not discrimination, underlie job segregation. Furthermore, raising the wages of "women's jobs" could discourage women from seeking higher paying "men's jobs," thus interfering with their choice, and could eliminate some jobs for willing pink collar workers. The liberty principle also leads the authors to oppose affirmative action goals or timetables because they are too outcome oriented, do not consider individuals as individuals, and impede the liberty of those who are denied jobs in favor of affirmative action candidates.

In the family realm, the liberty oriented approach requires the elimination of preferences for traditional family forms. ${ }^{42}$ It requires the end of gendered support and alimony laws; rather, government must leave these financial issues to private bargaining through procedures adopted to encourage private ordering. ${ }^{43}$ It requires an income tax system that focuses on the individual rather than the family, since family focused policies have tended either to penalize two income married couples or single people.44 Finally, it requires that government provide a children's allowance rather than direct subsidies for day care, so that individuals may make their own child care arrangements without government influence. ${ }^{45}$

In turning to their new analysis of the Supreme Court equality cases, the authors first criticize the prevailing approach, which compares men and women, because it begs the question that they see as fundamental: whether any of the asserted distinctions between men and women justify sex-specific constraints on liberty. ${ }^{18}$ The constitutional animus, in their view, "has more to do with constrictions on choice than with the desirability of sameness." as too unpredictable and malleable. ${ }^{48}$ They defend their liberty enhancing approach as more principled and neutral, and suggest that it can lead to more coherent outcomes than the various approaches taken by the Court.

\footnotetext{
41. P. 135.

42. Pp. 173-99.

43. Pp. 181-83.

44. Pp. $186-90$.

45. Pp. 190-94. The policy issues chosen for discussion are a curious assortment. Some, like the enforcement of marriage contracts and the income tax system, concern primarily the upper classes or address relatively minor aspects of the social and economic subordination of women. Yet the authors give very little attention to what many consider the crucial workplace issue facing women: the appropriate accommodation of maternity in the workplace. See Finley, supra note 1 . The authors mention this issue only as a passing observation in the chapter on paternalism, and state there that the provision of maternity leave is analogous to earlier protective legislation. P. 41. The authors do not even mention another currently important feminist issue: the regulation of pornography. The failure to discuss the pregnancy leave and pornography issues severely circumscribes the utility of a book that purports to be a comprehensive examination of gender justice.

46. P. 97.

47. P. 90.

48. Pp. 96-97.
} 
Although several cases have the same result whether the challenged policies are analyzed from the perspective of their effects on choice or from the perspective of justifications for the differentiation between men and women, some notable cases would have turned out quite differently under the liberty analysis. Rather than asking whether a gender distinction has a rational or substantial relationship to important governmental objectives, the equal liberty approach considers the impact of a policy on the life choices of men and women. ${ }^{49}$ In most instances, say the authors, this will mean removing gender specific criteria, because such criteria usually inhibit choice. Sometimes, however, autonomy can be furthered by gender defined opportunities, as in the area of sexual segregation. The authors are not troubled by the decision in Vorchheimer $v$. School District of Philadelphia, ${ }^{\text {s0 }}$ which upheld single sex public high schools, because single sex secondary schools do not create a badge of inferiority for either sex. As long as the educational opportunities are truly comparable, "offering males and females the chance to be apart, if only for a small portion of their lives, . . . afford[s] a richer mix of choices to everyone, and so [is] compatible with the idea of equal respect."\$1 By contrast, Rostker $v$. Goldberg, ${ }^{52}$ which upheld the limitation of draft registration to males, would have a different outcome under the liberty principle because a rule that categorically excludes women from an important civic obligation denies.their equal liberty by "signif[ying] that they are less than full members of the society." Harris $v$. McRae, ${ }^{\text {s4 }}$ which validated a law withholding Medicaid funding for medically necessary abortions, would also turn out differently. When Congress is denying "abortion funding to poor sick women while offering both men and women every other kind of medically essential treatment, it is constraining their liberty." When the government funds one outcome of pregnancy-childbirth-but not another possible outcome, it is burdening the choice of poor women. The authors are also troubled by the decision in Planned Parenthood of Central Mis-

49. For example, Kirp, Yudof, and Franks approve of the reasoning in Weinberger v. Wiesenfeld, 420 U.S. 636 (1975) (overturning provision of social security benefits to widows with dependent children, but not to widowers), which focused on the effect of law on choices of those who decided to follow nontraditional roles. Pp. 101-02. However, even where the results of the two analyses would be the same, the reasoning in some cases would be very different. The authors would analyze differently a case like Taylor v. Louisiana, 419 U.S. 522 (1975) (striking down exclusion of women from juries). In Taylor, the Justices focused on the unique perspective that women could bring to juries; the authors criticize this approach as perpetuating the stereotypes underlying the exclusion. They would simply declare the stereotypical attitudes and the exclusion to be liberty constraining. Pp. 103-04.

50. 532 F.2d 880 (3d Cir. 1976) affd by an equally divided Court, 430 U.S. 703 (1977).

51. P. 107.

52. 453 U.S. 57 (1981).

53. P. 105.

54. 448 U.S. 297 (1980).

55. P. 110. 
souri v. Danforth, ${ }^{58}$ which denied fathers a legal right to have a role in the abortion decision. While acknowledging that this case presents a classic example of conflicting liberties, the authors view the blanket denial to men of any liberty interest in the decision as a denial of their choice to have and rear children. ${ }^{57}$

It is certainly hard to argue with the noble ideal of equal liberty and equal respect for the capacity of men and women to make their own life choices that Gender Justice sets forth. Yet applying this principle can be a much more complicated and political endeavor than the authors' analysis contemplates. The authors overlook the ways in which power, domination, and the consequent social construction of gender roles affect choice and the configuration of community. Consequently, rather than serving as the voice that reinvigorates classic liberalism as the preferred approach to our society's thorny problems of gender dominance and differentiation, Gender Justice merely illustrates the inadequacies of that approach. In discussing the book's limitations, I will focus on three aspects: 1) the ways in which the choice principle, is not as outcome neutral, consistent, or coherent as the authors profess; 2) the book's failure to probe the meaning of "choice," and the implications of that failure for a freedom of choice approach in a society where race, class, ethnicity, and sex have a great deal of impact on one's life prospects and horizons; and 3) the ways in which feminist methodology offers a more constructive approach to the problem of gender justice than classic liberalism.

\section{The Illusory Neutrality of EQual Liberty}

The authors' advocacy of outcome neutrality raises the twin questions of whether it is really desirable or possible to be agnostic about social ends. If we accept the desirability of outcome neutrality, then where is there room, in the equal liberty approach, for concern about the effects of existing structures of social order, or for commitments to rectify or ameliorate felt inequities? Reducing such concerns simply to opposing certain practices because they constrain liberty does not sufficiently capture our moral intuitions. Is there any role in the liberty theory for moral outrage over practices such as the exploitation of female sexuality, the frequently casual attitude of law enforcement officials toward domestic violence, or the many other indignities faced by women? ${ }^{58}$

\footnotetext{
56. 428 U.S. 52 (1976).

57. Pp. $110-11$.

58. Although some aspects of these practices, with the possible exception of pornography, could be challenged as choice constraining, the dimension of moral outrage, which is lacking in the dispassionate choice-enhancing argument, expresses something fundamentally important about who we are as human beings, and how we want to live our lives.
} 
The authors might respond that such outrage has a place, for they are not extreme libertarians; they would not permit the exercise of choice in ways that fundamentally harm others. But what kinds of harm are sufficient to constrain liberty, and how do we evaluate whether something is harmful? For example, does the existing distribution of men and women in the workforce, and the corresponding wage gap, harm women? Yes, one might say, if these patterns are understood as the reflection of stereotyping assumptions, which-when combined with our society's traditional lack of support for maternity policies and child care-reduce choice and lock women into "women's jobs" and traditionally female roles. No, someone else who looks at the world quite differently might argue, this arrangement causes no harm because it reflects choices and preferences stemming from different values held by men and women.

These two plausible views of what is harmful and what is choice constraining illustrate that if we were really agnostic about social ends, we would not know how to apply the liberty principle. Since we would have no basis for choosing among different conceptualizations of a situation, what we viewed as liberty enhancing would depend in part on the outcome we considered desirable. A policymaker or judge would appreciate those aspects of social context that accorded with her personal values and political orientation. ${ }^{60}$ This becomes apparent upon closer examination of the situations to which the authors apply the principle of choice enhancement.

The authors analyze Frontiero $v$. Richardson ${ }^{60}$ extensively to illustrate the inconsistency of the Supreme Court's various equality approaches to sex discrimination, and the superiority of their own approach. Frontiero involved a challenge to a rule that entitled servicemen automatically to claim their wives as dependents eligible to receive benefits and PX privileges, but required a servicewoman to prove that her husband was economically dependent on her before he could receive benefits. The authors would uphold this rule under the liberty approach, because the rule did not infringe on anyone's liberty by denying to one sex a benefit conferred

59. Indeed, the authors' preference for outcome neutrality is not apolitical. Their resort to neutrality is based on a value-laden set of political choices and assumptions-the idea that individuals should determine their own conceptions of the good, the belief that justice can be determined according to abstract principles rather than particular or contextual conceptions of the good, and the disavowal of any community conceptions of virtue and justice imposed by the state. See Singer, The Player and the Cards: Nihilism and Legal Theory, 94 YALE L.J. 1, 40-41 (1984). Competing political visions, including republicanism and communitarianism dating back to Aristotle, when juxtaposed with the principle of liberty enhancing outcome neutrality, reveal its lack of neutrality. See, e.g., M. SANDEL, LIBERALISM AND THE LIMITS OF JUSTICE (1982) (critiquing view of human nature and justice underlying traditional liberalism); Sherry, Civic Virtue and the Feminine Voice in Constitutional Adjudication, 72 VA. L. REv. 543, 544-80 (1986) (contrasting individualist liberal paradigm with classical communitarian virtue paradigm).

60. 411 U.S. 677 (1973). 
on another. The rule simply made it more inconvenient for women to obtain the benefit. ${ }^{61}$ Looked at differently, however, the regulation impedes liberty because it reflects stereotypes about the respective roles of men and women within families, and helps entrench these stereotypes by causing economic consequences to turn on whether or not a family fits the traditional pattern. In addition, the regulation can be understood as invading the privacy, and thus the liberty, of servicewomen, because they must open their family economic affairs to public scrutiny, while servicemen need not. ${ }^{62}$

A set of cases that demonstrates nicely the vagaries of the choice principle is the series involving sex-based payment and contribution differentials in pension and life insurance plans. ${ }^{\text {BS }}$ While the Supreme Court struck down these differentials under antidiscrimination analysis, the liberty principle, the authors claim, would sustain the use of sex-based actuarial tables. Since life expectancy carries no stigma, using it as a decision criterion affects no one's liberty. "It strains logic to analyze pension or life insurance differentials as affecting the capacity of an individual to form and act upon a life plan." lytic context from the impact of differentials on an insured woman's working years to the impact on her life after retirement or on her beneficiaries after her death, the outcome of the liberty analysis changes. If a retired woman receives less in pension payments each month than the man she worked alongside for an equal number of years, isn't her liberty being constrained in relation to his? Her options during retirement may be fewer, because she will be able to afford less despite the same number of years of work. To say that she may live longer than her male co-worker, and thus may receive the same or more over the long run is no answer to the choice-constraining standard of living problem, because monthly or yearly income is much more important than overall income over a period of years in determining a retiree's daily life options.

It is surprising that such strong individualists as the authors are not more suspicious about the use of statistical generalizations that treat women as a class. In the context of workplace pensions, such generaliza-

61. Pp. 92-93. This analysis overlooks the fact that all married servicemen would get the benefit regardless of their family economic situation, while only certain exceptional servicewomen would get the benefit.

62. See Tong, Liberty, Equality-Community?, Women's Rev. Books, Jan. 1986, at 1 (review of Gender Justice).

63. See, e.g., Arizona Governing Comm. for Tax Deferred Annuity \& Deferred Compensation Plans v. Norris, 463 U.S. 1073 (1983) (state retirement plan paying lower monthly benefits to women than to men violates Title VII); City of Los Angeles Dep't of Water \& Power v. Manhart, 435 U.S. 702 (1978) (pension plan requiring female employees to make larger contributions than male employees violates Title VII).

64. P. 114. 
tions are indeed suspect, because the statistical data reflect, in part, traditional lifestyles and role constraints on women. One reason women have tended to live longer than men may be that they have not been exposed to as many occupational stresses and hazards. ${ }^{68}$ But as women enter into previously all male occupational preserves, they will be exposed to the same health threats. Thus, holding an individual working woman to the statistical patterns generated by the social roles of a slightly earlier generation may, indeed, impede her liberty by discounting the lifestyle that she has in fact chosen. When the general fact that women as a group live longer than men is placed in its social context, the outcome of the choice principle differs from the authors' application.

Affirmative action is yet another issue that can be resolved differently under a liberty analysis depending on one's political values and the social factors one selects for emphasis. The authors' position loses its veneer of neutrality and consistency when they acknowledge that race-conscious policies such as affirmative action hiring goals may be necessary to overcome the history of discrimination against blacks, but deny that similar policies are necessary in the realm of gender discrimination. ${ }^{68}$ The only apparent explanation for these disparate views is the authors' belief that racial discrimination is somehow more pernicious and harder to rectify than sexism. ${ }^{87}$ This is definitely not a neutral, objective position. When it comes to

65. The major empirical work outside the legal and insurance literature concludes that social, cultural, environmental, and behavioral factors are more important than genetic or biological factors in explaining sex mortality differentials. See Brilmayer, Hekeler, Laycock \& Sullivan, Sex Discrimination in Employer-Sponsored Insurance Plans: A Legal and Demographic Analysis, 47 U. CHI. L. REv. 505, 541-559 (1980) (summarizing demographic evidence of cultural factors that affect changing sex mortality differentials, including occupational and lifestyle factors).

As a generalizable, statistical matter, mortality rates also vary in the United States according to race, yet our society has long rejected as discriminatory the use of race-based mortality tables for insurance and benefit purposes. Id. at 536, 538. Nevertheless, some commentators who decry the use of race-based tables because they acknowledge that any statistical association between race and mortality is environmental or social, rather than genetic, fail to see that this is also likely to be true for a sex link. See, e.g., Kimball, Reverse Sex Discrimination: Manhart, 1979 AM. B. Found. RES. J. 83, 111-13; Randall, Risk Classification and Actuarial Tables as They Affect Insurance Pricing for Women and Minorities, in U.S. Comm'N ON Givil Rights: Discrimination Against Minorities and Women in Pensions and Health, Life, and Disability Insurance 527, 535-37, app. $A$ at 546 (1978).

66. Pp. 43-45, 137.

67. Indeed, the authors explicitly take this position. They argue that the inhumane and selfserving motivations behind race discrimination necessitate affirmative corrective measures to remedy the intentional disadvantaging of blacks. Conversely, they argue that such paternalistic measures are inappropriate in the gender context where special consideration would only reaffirm the "special" role of women. Pp. 43-45. While racism, of course, has long been a special problem for our society, this does not belie the fact that sexism has also shaped our polity. The phenomenon of sexism simply has not been subjected to as much scrutiny or evoked as much awareness as racism, and thus has been considered less of a problem. Some aspects of sexism are so pervasive that they are not even recognized as such, but instead are justified as the result of "natural" roles and differences. See, e.g., Finley, supra note 1, at 1129-34; Freedman, Sex Equality, Sex Differences, and the Supreme Court, 92 YALE L.J. 913, 931-40, 943-49 (1983). 
gender, the authors support process-oriented affirmative action policies designed to get more women to apply for traditionally male jobs, to evaluate selection criteria that may diminish women's opportunities to compete for jobs, and to replace gendered hiring standards with neutral standards. In their view, this consciousness raising style of affirmative action enhances liberty because it expands opportunities and choices. At the same time, they oppose result-oriented affirmative action, such as goals or quotas, because a quota can mean that an individual will be hired regardless of merit. This can stifle efforts to obtain skills and qualifications, and can discourage individuals from assuming responsibility for their own conduct and exercising their right of self-determination. Quotas are bad because they "deny the primacy of individuals, undermining the claim to equal consideration as a person that is the cornerstone of autonomy."

Although affirmative action quotas may be problematic for a variety of reasons, ${ }^{69}$ the authors' assertion that they infringe the liberty of their beneficiaries is certainly open to question. The existence of a quota does not compel any individual member of the desirable group who does not want the job to take it. In this sense, it does not impede choice any more than other opportunities.

Moreover, a hiring goal can be regarded as a much stronger expansion of opportunities for those traditionally excluded than the exhortations adopted under a process approach. Because such a goal increases the likelihood that an applicant from the traditionally excluded group will actually be hired, it expands that individual's choices and opportunities. It may also enhance the self-respect and self-determination of the individual members of the previously disadvantaged group, because they know that if they do develop skills and qualifications, they will actually have a chance of getting the job. In addition, a hiring goal may give employers stronger incentives to scrutinize their job criteria for stereotypes and biases than would a merely precatory policy about opening up job opportunities.

The real objection to affirmative action that Kirp, Yudof, and Franks seem to be voicing is that it constrains the choices available to those who previously had greater choices at the expense of others. But these were false opportunities, created by the unfair advantages acquired by the preferred group through its exclusion of others. The affirmative action debate obviously presents us with a situation of conflicting liberties: What may be necessary to enhance the opportunities of some will, at the same time,

68. P. 166 .

69. One of the reasons affirmative action policies can be problematic is that they can have a backlash effect: In the minds of members of the traditionally advantaged group, any woman or black who joins the workforce becomes suspect of being there, not because of qualifications, but as an "affirmative action baby." Such perceptions make it doubly difficult for the new workers to gain acceptance. 
constrict the opportunities of others. How one chooses to resolve this conflict in the context of affirmative action may depend on whether it is considered better to prefer the liberty of the previously disadvantaged, or whether it is better to preserve the choices of the advantaged group while hoping that less drastic, exhortatory policies will bring the opportunities of men and women into better balance. Neither is a politically neutral or outcome neutral position.

Kirp, Yudof, and Franks' arguments against comparable worth also can be stood on their heads. Some of the authors' arguments, such as the difficulty of making sensible comparisons ${ }^{70}$ and the dangers of bias creeping in through job evaluation systems, ${ }^{71}$ have little to do with their liberty principle. Their resort to arguments outside the scope of their neat framework raises doubts about their oft-professed outcome neutrality. It suggests a hostility towards the transformation of values and roles that is the deeper aspiration of the comparable worth movement. ${ }^{72}$

As for the effect of comparable worth wage scales on choice, the authors contend that the pay equity movement could hurt the choices of women who might be likely to seek traditionally male jobs. ${ }^{73}$ According to their argument, if a woman would be paid more as a nurse, maybe she wouldn't want to be a doctor; if paralegals were paid a true professional's wage, then maybe a young woman in this new women's job ghetto would abandon her aspirations to go to law school; if a woman could earn as much as her boss by being a secretary, then why would she want to be the boss? Aside from its dubious assumption that money is the main reason people choose certain jobs, this choice-based argument is internally contradictory because it implies that there are currently some people holding traditional male jobs who might really want to do "women's work" but feel they simply cannot afford to follow their preference. If money can coerce one group of people, it can coerce the other too. It seems equally plausible to argue that if the wage disparities between predominantly female and predominantly male jobs are narrowed, then both men and women will be freer to choose what they really want to do, without feel-

\section{P. 168.}

71. P. 169.

72. Indeed, the authors tip their hands to their value preferences when they denigrate an outcome in which "[w]omen could carry on at their familiar jobs as librarians and teachers and secretaries, at pleasantly unfamiliar wages, the system driven by an administrative apparatus which paid them according to their 'true' worth. That does not seem an especially salutary outcome." P. 171. This statement is insulting to women and to their traditional work, because it assumes that the work women do is neither important nor worth more than it now commands, and that no one would want to do that kind of work if higher paid men's work were readily available. It is precisely such biased assumptions that the underlying philosophy of the comparable worth movement challenges. Moreover, one is tempted to ask what our society would be like without teachers, librarians, nurses, and secretaries.

73. Id. 
ing economically compelled. Indeed, as the salaries paid for jobs such as schoolteachers and nurses have risen, greater numbers of men have begun moving into these positions. One could argue that the most choiceenhancing policy is to pay all jobs the same, so that all potential economic coercion is eliminated.

The authors again let values and biases slip into their supposedly neutral and consistent framework when they consider the coverage of pregnancy under disability benefit plans. They see this issue as a balancing of liberties problem: the interest of the employer and nonpregnant employees in not increasing aggregate costs of health benefit plans, versus the interest of pregnant women in securing coverage of maternity leave. But, in the authors' view, the latter interest is much less compelling. "Unlike other disabilities covered by employee health plans, pregnancy is usually voluntary and welcomed; because the medical costs associated with normal pregnancy are relatively low, the ordinary family can usually plan for them." Virtually every assumption underlying this argument is either erroneous or based on the life situation of the white, heterosexual, married, middle-class couple-quite surprising for authors who take great pains throughout their book to assert sensitivity to nontraditional lifestyles. Moreover, the argument completely ignores the way in which the lack of workplace accommodation of pregnancy historically has greatly impeded women's employment choices, and has entrenched the stereotypical and choice-constraining views of women's place in the home. ${ }^{78}$

It is not readily apparent how the voluntariness of pregnancy bears on the interests of women and men in having pregnancy coverage in an employer's health plan. ${ }^{78}$ The interest for providing such coverage comes from the importance that society traditionally has ascribed to pregnancy and the need for women not to sacrifice economic security because of their decision to get pregnant. Given that the voluntariness of pregnancy is irrelevant to the importance of pregnancy coverage in disability benefit and leave policies, one suspects that whether or not pregnancy is "voluntary" is not the real motivation behind the "voluntariness" argument. The argu-

74. P. 109.

75. See Finley, supra note 1 , at 1122-42.

76. It is hard to believe that the voluntariness of pregnancy was the real reason it was excluded from coverage. Most health benefit plans that excluded pregnancy covered other voluntary procedures, such as cosmetic or elective surgery. This was true of the plan excluding pregnancy that the Supreme Court upheld in General Elec. Co. v. Gilbert, 429 U.S. 125 (1976); see also Geduldig v. Aiello, 417 U.S. 484 (1974) (California insurance plan that excludes pregnancy does not violate equal protection).

The exclusion of pregnancy from disability plans has since been barred by the Pregnancy Discrimination Act of 1978, Pub. L. No. 95-555, 92 Stat. 2076 (codified at 42 U.S.C $\S 2000$ (k) (1982)). Moreover, pregnancy is not always voluntary in the sense of being consciously planned or welcomed. To assert that it usually is ignores failures of birth control devices and rape; it also overlooks the situation of the working poor who are already financially strapped by existing children, but who cannot afford abortion due to Medicaid funding restrictions. 
ment masks the traditional assumption that a woman's primary role is to have children, and that work outside the home is inconsistent with that role. While such an assumption is perfectly compatible with the view that it is important for women to bear children, it denies women the opportunity both to work and have children. Men, of course, have always been able to choose to engage in reproductive behavior with no adverse employment consequences. ${ }^{77}$ When viewed from this perspective, an employer's exclusion of pregnancy from its disability and leave plans constrains the liberty of women.

The authors' assumption that the costs of normal pregnancy are low in comparison to other items covered under health benefit plans is also questionable. With the current medical malpractice insurance crisis, which is hitting obstetricians quite hard, ${ }^{78}$ the costs of routine prenatal care and non-Caesarean deliveries can be as much as one thousand five hundred dollars. ${ }^{79}$ Caesarean deliveries, which are becoming more prevalent, can approach two thousand dollars. ${ }^{80} \mathrm{It}$ is doubtful whether most ordinary working families can easily absorb such costs, especially with the huge costs of rearing a child staring them in the face. But what of single mothers, and what about the working poor, and what about married women whose husbands are not employed?

In sum, the "voluntary," "welcome," and "inexpensive" arguments for denying economic security to pregnant working women and their families are heavily value-laden. They presuppose a view of the proper role and place of women and the appropriate relationship between women's reproductive roles and their desire to work. It is not an outcome neutral position to support exclusions that have kept women out of the workplace during their childbearing years.

The lack of objectivity and neutrality in the liberty principle is frequently apparent in situations acknowledged by the authors to involve conflicting liberties, ${ }^{81}$ or in instances where enhancing the liberty of an individual may conflict with the general welfare. ${ }^{82}$ Kirp, Yudof, and

77. See Kay, Equality and Difference: The Case of Pregnancy, 1 Berkeley WoMEn's L.J. 1, 21-37 (1985); Brief Amici Curiae of Coalition for Reproductive Equality in the Workplace at 7, 14, 21-22, California Fed. Sav. \& Loan Ass'n v. Guerra, 106 S. Ct. 783 (1986) (No. 85-494) (granting certiorari).

78. See N.Y. Times, Feb. 12, 1985, at A1, col. 1 (rising number of malpractice suits spurring some doctors to leave obstetrics).

79. Telephone conversation with Gisela Garthright, business manager for Obstetries and Gynecology at Yale-New Haven Hospital, New Haven, Connecticut (Nov. 11, 1986).

80. Id.

81. See, e.g., p. 110 (discussion of Planned Parenthood of Central Mo. v. Danforth, 428 U.S. 52, 67-72 (1976) (interest of potential father versus that of potential mother in abortion decision)); p. 107 (discussion of Mississippi Univ. for Women v. Hogan, 458 U.S. 718 (1982) (interest of male nursing student attending school in hometown versus interest of women students in single-sex education)).

82. Pp. 111-13. 
Franks offer little more than a good old balancing test to resolve these tensions: Figure out whose liberty will be hurt more, and choose the option that avoids this greater evil; or, evaluate the magnitude of the collective gain against the centrality to personal autonomy of the endangered individual interest. ${ }^{83}$

Such balancing tests, however, are highly contingent. The outcome depends on what factors are selected for emphasis and who is evaluating the relative strengths of the respective liberties. For example, if the decisionmaker is morally opposed to abortion, the father's interest in preventing an immoral act will be seen to outweigh any interest the woman has in doing that act. But if the evaluator thinks that a woman's right to control her reproductive capacity is vitally important to her selfrealization, and that a man's biological role in producing a child is of less duration and physical consequence than a woman's role, then the woman's liberty interest will clearly "win." There is no neutral, objective way to calibrate and compare the relative weights of two liberty interests, nor is the result of any balancing effort outcome neutral. Sometimes, a balancing test can simply be an invitation for the perspective and preferences of the traditionally powerful to triumph once again. ${ }^{84}$

This last observation suggests a further problem with Kirp, Yudof, and Franks' belief that their analysis is consistent and outcome neutral. They can be fairly criticized for overlooking the problem that in any society in which great disparities of power, wealth, and gender roles exist, the meanings of both "choice" and "choice-enhancing" are intensely political issues.

\section{The Meaning of Choice in a Gendered World}

At the outset of chapter four on "Gender in the Context of Community," Kirp, Yudof, and Franks allude to an issue that should be crucial to their choice analysis. Given that individuals "are profoundly affected by the communities in which they live," should "this realization . . . modify [the] conception of gender justice as grounded in individual choice .. . ?"'Bs What is the meaning of individual choice and self-determination within a social fabric of human interdependence and interaction where "reality" and expectations are more often than not socially constructed? The authors never grapple with this profound question. They virtually dismiss it when they state that "we object to a view of human nature that

83. Pp. 112-13.

84. For a critique of the indeterminacy and power reinforcing tendencies of balancing tests, see, c.g., Kennedy, Form and Substance in Private Law Adjudication, 89 HaRv. L. Rev. 1685, 1707-10 (1976); Singer, supra note 59, at $31-32$.

85. P. 67. 
rejects the proposition, key to liberalism, that women and men can shape their own lives, ${ }^{\prime 88}$ and then continue in chapter four to discuss only their ideal vision of an open community of diversity and tolerance. This dismissal misses the insight that each individual exists in the context of a community. Without denying the possibility that individuals shape their own lives, it is important to explore how individuals are shaped by their relations to others in ways that, in turn, affect how individuals shape themselves. To phrase the inquiry as a question: Given that an individual's race, class, ethnicity, religion, geographical location, and gender greatly affect his or her life options and character, what, in this context, is the meaning of "individual choice"?

Gender roles are creatures of powerful social construction, with some measure of biology thrown in. Whether someone is a man or a woman may be one of the most important factors in determining how others react to him or her, what is expected of him or her, and what horizons may be open to him or her. From infancy, girls and boys are subtly, and sometimes not so subtly, socialized into different roles. Girls are strongly socialized into the role of nurturer with its accompanying tasks of caretaking and household management, while boys are often expected to have little involvement in these aspects of family life. Girls and boys look at the world around them and see almost exclusively men doing certain jobs, and women others. This realization greatly affects their perceptions of the goals to which they appropriately should aspire. ${ }^{87}$

These perceptions are also affected by the very different messages given to boys and girls about what will give them social approval and connection, rather than isolation, and about what they should "want." Boys are encouraged in the traits of "masculinity"-be athletic, do not show emotions, be competitive, be aggressive, and set your sights high in the world, well beyond the private sphere of family. Girls are encouraged in the traits of "femininity"- do not be competitive or aggressive, place primary emphasis on cooperating, giving, and caring, even at the expense of your own needs, and do not be too ambitious, especially in wanting traditionally male attributes, because that could harm your prospects for happy personal relationships. ${ }^{88}$ Girls are taught: Set your sights on family and

86. Id.

87. For example, a friend of mine who feels he has tried very hard not to constrain his daughters in traditionally female ways told me about asking his young daughter what she wanted to do when she grew up. She replied that she wanted to be a stewardess. When he asked her whether she might want to be a pilot instead, she responded with that exasperated child's voice that signals that adults just don't understand, and told him that she couldn't be a pilot because only men are pilots. Her father responded that she indeed could be a pilot if she wanted, despite the almost total absence of women role models, but this little girl was already attuned to the dangers and difficulties of breaking out of conventional social roles.

88. For a discussion of the socialization into and the complexities of femininity, especially as they 
relationships, and of course aspire to a career, too, but just don't forget that your main concern should be your "private life." of a girl into femininity tends to go hand in hand with a message that she should accept her designated role, because striving too much for other roles could mean the horrors of social isolation, loneliness, and disapproval, and should focus her thoughts on the needs of others rather than on self-determination. Indeed, "self-determination" for a woman, more so than for a man, is often conceived in terms of her ties to others and the interests of those with whom she is connected..$^{90}$

Acknowledging the reality of socialization does not deny free individual choice or, for women in particular, the chance to break out of patterns of traditional socialization. But, the forces of socialization are powerful and can be especially powerful in the way they shape those without societal power. For the powerless, the consequences of defying socialization are more problematic. If you are in a situation of economic and social dependency, trying to break out of a traditional role can mean the loss of that upon which you depend for survival. As the feminist theorist and political scientist Kathy Ferguson has observed:

Part of the perniciousness of femininity in our society is that it produces people who claim to choose what they are supposed to want, and claim to want what they have. Once acknowledging the ways in which knowledge and power are dialectically bound together, it becomes an act of viciously acquired naivete to equate all expressed - preferences with self-defined interests. $^{91}$

A discussion of gender justice that focuses on individual choice is incomplete without consideration of the significance of being a woman in this largely male-defined society, and its implications for self-determination. To be a woman in this society may mean being physically vulnerable to abuse and sexual exploitation and imposes consequent constraints on one's actions. It means having to take principal responsibility for caretaking tasks; often these tasks must be put ahead of other responsibilities and a

relate to ambition, see S. BrownmiLler, Femininity 221-31 (1984).

89. This continued societal ambivalence about women holding "male" careers lurks behind the recent media attention to the diminishing marriage prospects for women after their late twenties, especially women who have delayed attention to personal concerns until after establishing careers. See, e.g., Too Late for Prince Charming?, NewsweEk, June 2,1986, at 54. There is an implicit condemnatory message in stories such as the Newsweek piece. Women are being chided for striving after nontraditional roles, and are being told by the media that they have gotten their comeuppance in the form of personal unhappiness and that most horrible of fates-spinsterhood and childlessness. Meanwhile, men are not criticized for putting career ahead of family. Cohen, What's a Woman To Do?, Washington Post, May 31, 1986, at A23, col. 8.

90. C. Gilligan, supra note 27. This work casts doubt on the traditional, male-defined concept of self-determination as something that can be achieved wholly apart from connections to others.

91. K. Ferguson, supra note 23, at 177 (1984). 
woman's own needs or else they will not get done. The qualities and skills that women traditionally are taught to develop are not those highly valued in the public work world; consequently, when women enter that world, they find an environment largely insensitive to caretaking responsibilities. If women demonstrate the male traits that are valued in the public world, such as competitiveness, assertiveness, or physical strength, they may find that they are viewed with suspicion or outright hostility and they may be labelled too bitchy or uncooperative to deserve promotion. ${ }^{92}$ In this context, trying to pursue a nontraditional path can mean isolation, lack of supportive role models, and far greater personal sacrifices than those faced by men following the same paths. It may also mean having to cope with a sense that you may be crazy, maladjusted, incompetent, or simply "out of synch" with the world. ${ }^{93}$ Is it any surprise, then, that women may "choose" to follow traditional roles and jobs, and "not want" certain positions that are structured around the traits and interests of the men who have traditionally occupied them?

At this point, Kirp, Yudof, and Franks would probably object that I am just another deterministic, leftist feminist, who subscribes to the oppression theory by portraying women as victims who have no responsibility for their plight. Such an objection would misstate and grossly oversimplify this "leftist feminist" position, and would fundamentally miss its point. Leftist feminism is not a conspiracy theory that attributes conscious design to all men and absolves women of all responsibility for their lot. ${ }^{94}$ Rather, analysis of the ways in which women are oppressed explores how the options, choices, and dignity of women have been systematically constrained by their powerless positions throughout history. Women have been excluded outright from most domains of the public world. They have been classified by political theorists as nonpersons or as morally deficient human beings. ${ }^{95}$ They have been labeled by the law as the property of

92. See, e.g., Hopkins v. Price Waterhouse, 618 F. Supp. 1109 (D.D.C. 1985). Judge Gesell found that an accounting firm had practiced sex discrimination in violation of Title VII when it used a subjective, male-dominated evaluation system to block the promotion of a woman to partner because of her aggressive style, a style that the firm tolerated in men. Id. at 1118-20.

93. Virginia Woolf discusses the personal and social penalties suffered by women who dared to be different. V. WOOLF, A RoOM OF ONE's OWN 62-86 (1929). In analyzing the question why there have been no great women artists, writers, or composers, she chronicles the social opprobrium that any woman who dared to engage in these activities would have faced. Id. at 74-75. Yet, despite the barriers that obstructed them, some women did become artists, although some of them had to publish under men's names. This example from history demonstrates that social expectations can indeed affect choice.

94. Indeed, many feminist writers have discussed the ways in which women have been complicitous in maintaining patriarchy. See S. Brownmiller, supra note 88; S. De Beauvolr, The SECond SeX, 475-698, 663-98 (H. Parshley trans. 1974); M. French, Beyond Power (1985).

95. See, e.g., A. JAGGAR, supra note 1, at 36-37 (discussing views of Aristotle, Hume, Rousseau, Kant, Hegel, and Freud that women are inferior to men in their capacity for rational thought and moral agency); S. Okin, Women in Western Polittical Thought (1979). 
their fathers or husbands and have been considered akin in status to children and mental incompetents. ${ }^{96}$ The public world has been structured to be blind to the experiences, perspectives, needs, capacities, and contributions of women. ${ }^{97}$ These facts highlighted by the oppression argument demonstrate that simply removing some of the obvious constraints imposed on women does not automatically create a world of unconstrained opportunity and full self-determination. Fundamental power relations are not easily changed, nor are the imprints left on women's consciousness and self-conception. Moreover, the typically female virtues of being sweet, helpful, agreeable, emotional, sentimental, obedient, and self-effacing continue to lead more readily to subordination than to autonomy. ${ }^{98}$ The "oppression argument" is really the analysis of the social, psychological, and legal consequences of powerlessness. The insights of this analysis lead to the realization that abstract concepts such as liberty and freedom of choice are problematic in a gendered world. Many aspects of being a woman in this culture blur the seeming clarity of a concept such as "choice." is true even if we accept Kirp, Yudof, and Franks' premise that we each have a will that exists wholly apart from our social conditioning. Under their view, our independent will is not shaped by social context; nevertheless, even accepting their premise it remains true that we may make decisions with an appreciation for their social consequences.

Absent any sensitive discussion of the effects of the social construction of

96. For descriptions of these treatments of women, see Polan, Toward a Theory of Law and Patriarchy, in The Pourtics of LAw 254 (D. Kairys ed. 1982); Taub \& Schneider, Perspectives on Women's Subordination and the Role of Law, in id. at 117. This history makes the authors' assertion that women experienced a far different situation from blacks seem ludicrous. See supra notes 28-37 and accompanying text. The very fact that the authors can so blithely conclude that women have only been the object of solicitous protections, rather than of any deeper discriminatory animus, illustrates how sexism is so firmly entrenched and accepted that it is often invisible or at least is not acknowledged as the invidious creature that it is.

97. This blindness permeates the educational system, too. For example, in teaching history the traditional focus is on male activities, such as politics and war, while women's contributions to these activities are largely ignored, except for a few nurturing angels of mercy or boyish maidens hearing the voice of God. Defined as outside the scope of history, and thus not relevant to our current existence, are the areas of daily life in which women have figured prominently. For works of feminist scholarship seeking to correct the omission of women from history, and to explore societal structures that have rendered women's experiences invisible to history, see G. LERNER, ThE MAJORITY FINDS Its Past (1979); A. Scott, Making the Invisible Women Visible (1984); Liberating Women's History (B. Carroll ed. 1976); Politics and Culture in Women's History: A Symposium, 6 FeMinist StUd. 26-64 (1980).

The traditional view of what kind of education people need has also been dominated by male activities and traits - the world of production, rather than the world of reproduction and nurturing. This has contributed to the devaluation of qualities associated with women, and has further constrained women's choices and self-determination by subtly teaching them that their roles and experiences are relatively unimportant. See J. Martin, Reclaiming a Conversation Ch. 7 (1986).

98. K. FERGuson, supra note 23, at 191.

99. Men, of course, are forced into masculine roles by the process of socialization and the obligations of social and cconomic dominance. Breaking out of traditional male roles can be as isolating for men as breaking from female roles is for women. 
gender roles, the principle of equal liberty can become a powerful justification for the status quo. The existing order can too easily be seen as the result of "natural" preferences, without any examination of whether the values defining certain jobs or societal institutions sufficiently reflect the experiences and needs of both men and women. In places, Gender Justice displays this tendency to accept the status quo. For example, the authors accept the current division between the functions and values of the public and private spheres, and speak as if the quest for liberty and equality concerns only the public sphere. ${ }^{100}$ They do not grasp the ways in which this false dichotomy has contributed to the unequal status of women and continues to place many women in situations where choice is an illusory concept. ${ }^{101}$ Nor do they consider that the public world of work might be a much more humane place if it incorporated some of the values of the private world, or that the private world might not remain "inherently unequal"102 if it were not so sharply divided from the public.

The book's discussion of job segregation also illustrates the potential of a theory based on an abstract principle of choice to exalt the status quo. While laying some blame upon gender discrimination, ${ }^{103}$ the authors insist upon an additional explanation for why so many more women than men are nurses, schoolteachers, secretaries, and domestic workers: Women often choose these positions because the jobs demand a limited commitment, use women's nurturing skills, and offer the kind of part-time or relocational flexibility that enables women to combine their home and family responsibilities with minimal strain. Thus, say the authors, the market "partially mirrors personal preferences," and it is only natural and a reflection of choice that women shape work around the demands of home life, while men place work ahead of family. ${ }^{104}$ This explanation is replete with inaccuracies about the commitment requirements and flexibility of "women's work"10s and displays startling insensitivity to the social construction of roles, choices, and expectations. Deeply held notions about the proper role for women-notions which seem incompatible with a free choice theory-have strongly influenced the fact that women structure

100. Pp. 18-19, 199-200.

101. For discussions of how the public/private, market/family dichotomy has affected women, see K. O'Donovan, Sexual Divisions in Law (1985); Finley, supra note 1; Olsen, The Family and the Market: A Study of Ideology and Legal Reform, 96 HARv. L. REv. 1497 (1983).

102. P. 200.

103. Pp. $149-50$.

104. Pp. $150-51$.

105. It is false and demeaning to women to assert that jobs such as nursing or teaching require limited commitments or little in the way of training or intellectual upkeep. It is also false that "women's work" is more flexible. Often, pink collar ghettos have rigid time and hour expectations, and provide few fringe benefits, thus further locking women into their state of economic dependency. See S. Kamerman, A. Kahn \& P. Kingston, Maternity Policies and Working Women 49, 57, 141, 143 (1983); Frug, supra note 27, at 57-58. 
their work lives around family. How many women have been told, over time, that they can only work if they can also keep up the household? How many women would really choose to have two full-time jobs, one for pay, and one without remuneration, appreciation, or assistance from their partners, if social attitudes and expectations did not operate as constraints?

Labor market structures often force the family commitment on women: Because most women earn less than their partners, they are the ones most able to give up full-time work with the least impact on the family income. Conversely, the labor market also forces men to forego family involvement, by denying men leave opportunities for childrearing and by penalizing the career advancement of any man who does try to disengage, even temporarily, from the workplace in order to participate in home life. Yet these workplace structures are not inevitable, as Kirp, Yudof, and Franks' discussion of preference seems to assume. If the authors were really committed to the creation of more meaningful opportunities for men and women to choose to break out of traditional patterns, the structure of the labor market would be one of the first places to start a profound reexamination. The existing male model of employment would have to be challenged, and choices available to women would have to be defined to include more than just the option of assimilating into the current male defined workplace structures.

Kirp, Yudof, and Franks' discussion of women's job preferences reminds me of the opinion in EEOC v. Sears, Roebuck \& Co., ${ }^{106}$ a recent judicial decision whose acceptance of this sort of choice analysis has been the subject of sharp scholarly debate among feminist historians. ${ }^{107}$ One of the allegations of sex discrimination concerned the far lower numbers of women than men occupying the higher paid commission sales positions throughout Sears. The statement of qualifications for these positions reads like a description of the stereotypical male: someone who is aggressive, competitive, has lots of drive, physical vigor, and social dominance, someone with technical knowledge and fluency, someone who could frequently work odd evening or weekend hours. ${ }^{108}$ People with prior experience selling technical product lines were preferred, and personnel interviewers often evaluated candidates according to how closely they matched those already doing the job, ${ }^{109}$ a comparison group that was almost totally male. Perhaps recognizing how unlike their conceptions of themselves these very

106. 628 F. Supp. 1264 (N.D. Ill. 1986).

107. See Sears Bias-Case Ruling: No "Parade of Horribles," Chron. Of Higher Educ., Mar. 12, 1986, at 44 (letter to editor from Rosalind Rosenberg); Two Scholars' Conflict in Sex Bias Case Sets Off Wat in Women's History, Chron. OF Higher Educ., Feb. 5, 1986, at 1.

108. Sears, 628 F. Supp. at 1290.

109. Id. 
male job descriptions were, most women who did apply to be sellers for Sears stated a preference for selling noncommissioned and very female products-jewelry, lingerie, cosmetics, and women's apparel. ${ }^{110}$

Sears defended the statistical disparity between men and women in the commissioned jobs by arguing that it was due not to discrimination, but to women's preferences and choices. ${ }^{111}$ The court, relying on the views of experts who spoke of the qualities of femininity, accepted the position that any disparities were attributable to different interests and aspirations of men and women regarding work. ${ }^{112}$ According to the expert testimony, women's family obligations would make it either difficult or impossible for them to meet the hour demands of the commission sales jobs, and therefore women would shy away from those positions. Women, it was claimed, are less assertive than men, and like work atmospheres that entail cooperative, friendly relations with colleagues, rather than dog-eat-dog competitiveness. ${ }^{113}$

The court finds that women also do not like to accept financial risk as much as men; ${ }^{114}$ this is perhaps because their economic dependence and their principal responsibility for children can make monetary risk a suicidal course. Women's education makes it less likely that they will have the requisite technical background, comfort, or confidence in their ability to master technical information. For all these reasons, it was not surprising that Sears encountered difficulties in attempting to convince women to apply for positions selling machinery, home improvement devices, and automotive products.

Under the authors' choice analysis, the argument based on women's nature ends the inquiry. Men and women simply are different, and that means they have different interests. Government should do nothing to disturb these natural preferences. ${ }^{115}$ But instead of satisfying these choice

\footnotetext{
110. Id. at 1306.

111. Id. at 1305 .

112. Id. at 1315.

113. Id. at 1307.

114. Id.
}

115. Those who use observed differences between men and women to justify existing role disparities might try to exploit feminist analysis like that found in C. Gilligan, supra note 27, which speaks of the different moral orientations of men and women. See, e.g., Barber, Beyond the Feminist Mystique, New Republic, July 11, 1983, at 26 (using work of Gilligan to argue that inherent, immutable sex differences may be undoing of traditional feminism's goal of equality between men and women); Kerber, Greeno, Maccoby, Luria, Stack \& Gilligan, in In a Different Voice: An Interdisciplinary Forum, 11 SIGNS 304, 304 (1986) (Kerber, criticizing Gilligan's analysis as tending to entrench ideas of differences and status quo). But this type of justification is a serious misuse of Gilligan. Her work does not describe immutable differences between men and women; rather, it suggests that existing ways of measuring human development may not be sufficiently reflective of the range of orientations and perspectives of men and women. See id. at 524 (reply by Gilligan). Indeed, Gilligan's message is compatible with what I call the radical perspective on choice. See infra text following note 117. 
advocates, these supposedly preference-based disparities between men and women could lead to profoundly important inquiries about liberty. These inquiries would suggest how men and women could be liberated from the powerful constraints set by the social construction of gender roles. First, rather than blaming women and their nature for their underrepresentation in the high paying jobs, why not reexamine the jobs and their values? It may not be necessary for a salesperson to be an aggressive hustler willing to pester the customer to sell the commissioned items successfully. It may not be necessary to pit salespeople against each other; they could cooperate as a team working for the good of the division rather than the glory of any individual. There may be a way to accommodate the family responsibilities of women with the need for a salesperson to be available whenever a customer calls. Second, is the qualifications personality profile really geared to the needs of the job, or does it merely describe those who have been doing the job and the way they have been doing it? Just because a particular set of traits seems to produce sales, another approach is not necessarily doomed to failure. ${ }^{116}$ It may be useful to reexamine the designation of some items as commission items and others, usually associated with women, as noncommission, and thus less "important" and remunerative to sell. The designations, which Sears might seek to attribute to sales volume and profit margin, ${ }^{117}$ may be more directly linked to the notion that some of the jobs will be done by men and some by women. Finally, should it be of any concern to an equal liberty advocate that when a woman sees the male bias in the job itself, she may sense that she is not wanted or would suffer isolation and hazing on the job, and instead may cope with the odds against her by convincing herself that she really does not want what she probably would not get? A woman's "choice" to accept a traditionally female sales position may not be such a free one, after all.

The aim of these questions is not to suggest that preference analysis is invalid, or that the choice principle is undesirable, but to raise again the issue of the meaning of choice. These questions suggest that a libertyoriented approach could be reconceived as quite radical, if the goal is to weaken the biases based on socially constructed notions of gender that currently skew the choices of women and men, in order to liberate men and women from the confines of existing expectations. The radical ap-

116. This discussion is not intended to imply that the government should force Sears to restructure its jobs for women, and thereby cause it to suffer at the hands of competitors who will now be able to outhustle Sears. The point is that there is more than one way to sell something, and the hard sell hustle may not turn out to to be the only or most successful way. Therefore, I am not proceeding on the assumption that Sears would be playing sacrificial lamb if required to eliminate male bias in its job conceptions.

117. See Sears, 628 F. Supp. at 1289. 
proach would critique the value of such dichotomies as public and private, aggressive and cooperative. It would examine the impact on women of the male orientation of jobs and institutions, and women's perceptions of their opportunities and "fit" with such jobs and institutions. It would seek to open up institutions in both the public and private worlds to the perspectives and experiences of both men and women, so that good interpersonal skills, caring, cooperation, and flexibility to meet personal needs would be valued in the business world, and respect for individuality would be valued in the home world.

This conception is not, of course, what Kirp, Yudof, and Franks have in mind when they write of enhancing choice, because it is not outcome neutral. While this more radical conception does not presuppose some ideal proportion of men and women in each position, including childrearing, it does see the desired outcome as integrating the perspectives and experiences of both genders in both the public and private worlds. Ultimately the dichotomies between these worlds would be blurred, the constraints on self-determination imposed by social constructions would be loosened, and the social constructions of gender roles would themselves change.

This transformation would require far more interventionist policies than those with which Kirp, Yudof, and Franks would be comfortable. On the assumption that people exposed to new possibilities begin to change their attitudes, government might require employers to grant parenting leave and create incentives for men to take it. Employers might need to restructure their advancement tracks, so that those of either sex who assume parenting obligations need not sacrifice their careers. Employers might need to reevaluate the skills or traits currently considered desirable for certain jobs. Government could provide incentives to try things in new ways. It might even inaugurate affirmative action for men in traditionally female jobs, as well as for women in traditionally male jobs. Such significant departures from existing practices would be much more likely to result in what Kirp, Yudof, and Franks profess to want: a world in which men and women can exercise the full range of options previously available primarily to the other sex, without risking undue economic loss or social disapprobation for nontraditional choices, and a world in which one's gender is not as determinative as it is now of what one can do or wants to do.

\section{Feminist Methodology and the Critique of Abstract INDIVIDUALISM}

The failure of Gender Justice to grapple with the meaning of "choice" in a world of power disparities-one in which who we are, or can be, is 
greatly affected by gender roles and our interdependence with other human beings-is attributable to an underlying analytic flaw in the book. It is written in a distanced, coldly analytic tone. It is remarkably acontextual and abstract, despite its frequent attention to specific policy issues. The discussion proceeds with virtually no consideration of flesh and blood people; there is almost no reflection on the real world impact of the policies at issue, particularly in the way these policies have shaped people's lives and choices. There is little attention to history.

In all these failings, the book contains no hint of the influence of feminist methodology. By this term I mean paying close attention to context, such as the social construction of gender roles, and to the impact of practices on real lives, especially women's lives; challenging objectivity and the possibility of writing without a predetermined perspective or set of desired outcomes; rebelling against abstraction and professions of neutrality, because sensitivity to context and women's experience teaches that what is claimed to be neutral is not. ${ }^{118}$

The feminist rebellion against abstractions and neutrality does not mean theory must be abandoned. Rather, it means that theory must be drawn from and inspired by concrete experience and human interaction. Theory developed in this way can provide useful guidance for complex, real issues, ${ }^{119}$ and is not abstract in the same way as theory derived from overarching "neutral" principles, such as "equality" or "liberty."120

Why is it important, or a fair criticism, that Gender Justice is not influenced by the insights of feminist methodology? The answer is emphatically not that only those who consider themselves feminists should write about women's issues. It is that the lens of abstraction is not the most productive one for grappling, in a way that can actually affect people's lives, with the problems of gender domination. The lens of feminist methodology offers a more promising approach. The pursuit of gender justice

118. Women's experience and sensitivity to context challenges traditional methodologies. See Vickers, Memoirs of an Ontological Exile: The Methodological Rebellions of Feminist Research, in Feminism in Canada: From Pressure to Politics 27 (G. Finn \& A. Miles eds. 1982).

119. The work of Catharine Mackinnon is a powerful example of theory developed by feminist methodology. MacKinnon, supra note 1; MacKinnon, Feminism, Marxism, Method and the State: Toward Feminist Jurisprudence, 8 Signs 635 (1983).

Her analysis of the way in which males have perpetuated their power and domination through the definition and manipulation of female sexuality is not abstract in the conventional sense, because her theory is grounded in the experience of women. It is inspired by a close observation of human interaction and examination of feelings of anger, powerlessness, and invisibility. Reading MacKinnon provokes anger, flashes of recognition, identification with her subject, and enlightenment about actual experiences in a way that reading Hegel, Rawls, or Nozick simply does not.

120. Cf. J. RAwLS, A THEORY OF Justice 136-42 (1971) (decisionmakers must place themselves behind veil of ignorance of their own or anyone else's life situation to choose fair policies). Abstract theories such as this look only occasionally to real problems of daily life to see if the theory can be useful. When one considers a problem using a predetermined set of principles, one tends to see only that to which the theory directs. 
must be about reclaiming and understanding women's experience, including the ways in which the law has affected women and women have affected the law. It must strive to relate theory to, and have theory informed by, the reality of daily lives and experiences. ${ }^{121}$

The questions that are asked within a feminist methodology may make all of us leery of hidden biases, lurking beneath supposedly neutral, abstract universals, such as process or liberty. We will understand that without contextuality, abstractions are incomplete stories. When we analyze "freedom of choice" in the context of gender roles and human interconnectedness, we can understand that it is a complicated, multi-layered idea.

Attention to context does not mean simply telling stories about individuals, or performing a "microphenomenological" analysis that focuses primarily on small, local events or interactions. ${ }^{122}$ Feminist methodology can be quite global in the problems it tackles, such as the pervasiveness of male domination and its sexual, political, and economic roots and implications. A contextual analysis starts not with abstract principles, but with a sensitivity to the ways in which lives are constrained, shaped, or empowered by practices, whether they are government policies or lack of policies, or deeply held social ideologies and stereotypes. It is an analysis that seeks to avoid generalizations based on the experiences or needs of one dominant group, such as the white, employed middle-class, by remaining attuned to class, race, and gender variances among social practices and their effects. ${ }^{123}$ But this leeriness of generalities and abstractions does not imply perpetual relativism. Urging attention to the context and the complexity of abstract ideas in practice is not to say there are no answers or concepts of

121. See, e.g., Schneider, The Dialectic of Rights and Politics: Perspectives from the Women's Movement, 61 N.Y.U. L. REv. (forthcoming 1986) (describing feminist litigators' reliance on women's experience to formulate new legal claims regarding battering, reproductive freedom, and sexual harassment).

122. Cf. Boyle, The Politics of Reason: Critical Legal Theory and Local Social Thought, 133 U. PA. L. REv. 685 (1985) (developing "microphenomenological" approach).

123. While the authors do occasionally make statements that suggest sensitivity to the context of race, class, poverty, and gender, their policy analysis belies any deep appreciation of the context to which they allude. For example, in discussing child care, they state that "If]or poor parents, usually mothers, the choice between finding a job and staying home is illusory." P. 192. The authors then advocate a general family allowance, rather than expanded government child care programs, as the most liberty enhancing solution because it will enable poor mothers either to purchase child care or to mind their children at home. P. 194. But where is this welfare mother supposed to purchase child care, if that is her preference? There are far fewer child care facilities than can meet current needs, partly because such a female activity is generally devalued in "the market." Moreover, experience indicates that the cost of private child care, whether in a center or by an individual worker, is still likely to be far beyond the means of a poor woman, even with a government child care allowance. While government operated child care centers may turn out to be inferior in staffing and resources to some private centers and a poor woman may not have a real choice between government centers and private arrangements, the actual availability of the public center resource to a poor woman may nonetheless make the "purchase child care and work" option a far more viable choice than would the provision of a family allowance. The latter, when filtered through political reality, is not likely to amount to much more than an inadequate supplement to meager AFDC allowances. 
right and wrong. It is instead to say that close attention to context and experience is a more reliable guide than abstract theory to determine how government policies will affect or have affected people. Appreciating the varieties of perspectives, needs, options, and effects does not disable us from arriving at conclusions or recommendations. It simply means that the conclusions about what may be "choice-enhancing" are likely to be far different from the conclusions derived from unexamined general principles.

\section{CONCLUSION}

Feminist methodology leads to the examination of the meaning of "choice" in a gendered world. This examination of women's experience and socialization as bearing on their choices and aspirations produces different questions than those usually asked by the traditional approach, which seeks to fit the woman to the male job. This refined set of inquiries ultimately leads one to question the dichotomies and the assumptions around which Gender Justice is structured. Why should the autonomy of a self unaffected by others be the goal of human life? Why not promote altruism, responsibility, and interconnection as the primary aspirations? These aspirations are not incompatible with freedom, unless freedom is defined as complete disconnection from others. But how many people really want that kind of freedom? The freedom most of us want is the freedom to establish relationships with whomever we want, to base those relationships on mutual respect and care rather than domination and dependency, and to live in a world where public institutions respect and appreciate the obligations created by relationships. To reach that world it will be necessary to do far more than refrain from interfering with existing "choices" that grow out of the currently prevailing power structure, roles, and expectations of our society. 